\title{
Release efficiency and selectivity of four different square mesh panel configurations in the Basque mixed bottom trawl fishery
}

\author{
Elsa Cuende ${ }^{1}$, Luis Arregi ${ }^{1}$, Bent Herrmann ${ }^{2,3}$, Manu Sistiaga ${ }^{4}$, Mikel Basterretxea ${ }^{1}$ \\ ${ }^{1}$ AZTI-Tecnalia, Marine Research Division, Txatxarramendi ugartea w/n, Sukarrieta, 48395, Spain. \\ (EC) (Corresponding author) E-mail: elsacuende@gmail.com. ORCID iD: https://orcid.org/0000-0002-5787-5612 \\ (LA) E-mail: larregi@azti.es. ORCID iD: https://orcid.org/0000-0001-6273-3654 \\ (MB) E-mail: mbasterretxea@azti.es. ORCID iD: https://orcid.org/0000-0001-7684-4398 \\ ${ }^{2}$ SINTEF Ocean, Fishing Gear Technology, Willemoesvej 2, Hirtshals, 9850, Denmark. \\ ${ }^{3}$ The Arctic University of Norway, UiT, Breivika, Troms $\varnothing$, N-9037, Norway. \\ (BH) E-mail: Bent.Herrmann@sintef.no. ORCID iD: https://orcid.org/0000-0003-1325-6198 \\ ${ }^{4}$ Institute of Marine Research, Postboks 1870 Nordnes, Bergen, 5817, Norway. \\ (MS) E-mail: Manu.Sistiaga@hi.no. ORCID iD: https://orcid.org/0000-0002-0750-0900
}

\begin{abstract}
Summary: Reduction of discards from the Basque mixed bottom trawl fishery is a challenge. To improve the selective properties of the gear used by the fleet and supplement codend size selection, a square mesh panel (SMP) installed in the upper panel of the trawl was introduced in 2006. However, recent studies have shown that the release efficiency of this SMP is low due to lack of contact between the fish and the SMP. In this study, we tested the release efficiency of the SMP for four different gear configurations. We tested the effect of adding LED lights at two different positions and altering panel size and panel position in the trawl. The analyses were focused on two species: hake (Merluccius merluccius) and blue whiting (Micromesistius poutassou). The results showed that the position of LED lights did not significantly affect the SMP's release efficiency for any species. However, increasing panel size had a significant positive effect on the release efficiency of blue whiting, and placing the SMP in the lower panel improved the release efficiency of hake. These results highlight the challenge of simultaneously improving the selective properties of gear for species with different behaviour, especially in mixed demersal fisheries.
\end{abstract}

Keywords: square mesh panel; LED lights; trawl fishery; release efficiency; hake; blue whiting.

Eficiencia de escape y selectividad de cuatro configuraciones diferentes aplicadas a un panel de malla cuadrada en la pesquería multiespecífica de arrastre del País Vasco

Resumen: La reducción de descartes en la pesquería de arrastre del País Vasco supone un problema importante. En 2006, se introdujo en la reglamentación la posibilidad de usar un Panel de Malla Cuadrada (SMP) en la zona anterior al copo para mejorar la selectividad de la red. Sin embargo, estudios recientes manifiestan que la eficiencia de escape de los peces es baja debido a la falta de contacto selectivo entre el pez y el panel. En este estudio, analizamos la eficiencia de diferentes configuraciones del SMP. Se analizó el efecto de luces LED colocadas en distintas posiciones, el efecto del tamaño del SMP y su localización. Estudiamos la merluza (Merluccius merluccius) y la bacaladilla (Micromesistius poutassou). La posición de las LED demostró no tener ningún efecto significativo sobre la eficiencia de escape del SMP para ninguna de las dos especies. Sin embargo, aumentar el área del panel tuvo un efecto significativo en la eficiencia de escape de la bacaladilla, mientras que el cambio de posición del SMP incrementó la eficiencia de escape de la merluza a través del SMP. Estos resultados muestran el reto que supone mejorar la selectividad de un arte de pesca simultáneamente para especies demersales con comportamientos diferentes.

Palabras clave: panel de malla cuadrada; luces LED; pesca de arrastre; eficiencia de escape; merluza; bacaladilla.

Citation/Como citar este artículo: Cuende E., Arregi L., Herrmann B., Sistiaga M., Basterretxea M. 2020. Release efficiency and selectivity of four different square mesh panel configurations in the Basque mixed bottom trawl fishery. Sci. Mar. 84(1): 39-47. https://doi.org/10.3989/scimar.04975.17A

Editor: P. Sartor.

Received: July 4, 2019. Accepted: November 12, 2019. Published: January 28, 2020.

Copyright: (c) 2020 CSIC. This is an open-access article distributed under the terms of the Creative Commons Attribution 4.0 International (CC BY 4.0) License. 


\section{INTRODUCTION}

The landing obligation established under the new Common Fisheries Policy (EU 2013) aims to eliminate the discard of commercial species and represents a big challenge for mixed fisheries with large quantities of discards (de Vos et al. 2016). The Basque demersal bottom trawl fishery operating in the ICES VIIIabd area is one of such fisheries. Total catch includes more than 100 different marine species, and the fishery is subject to large quantities of discards ( $\sim 60-65 \%$ of the total catch in the period 2011-2013; Rochet et al. 2014).

According to the regulations specified by the European Commission (EC 2006), the vessels participating in this fishery usually use a trawl net with a $70 \mathrm{~mm}$ diamond mesh codend combined with a $100 \mathrm{~mm}$ square mesh panel (SMP) (2 $\mathrm{m}$ long, $1 \mathrm{~m}$ wide) inserted in the upper panel of the extension piece of the trawl. However, recent studies have shown that most undersized individuals that escape the gear do so through the codend rather than through the panel (Nikolic et al. 2015, Alzorriz et al. 2016).

Mesh size modifications in the codend are often not well received by fishermen because they may lead to potential loss of economically valuable fish (Bahamon et al. 2006). On the other hand, SMPs can be an alternative measure to increase the escape of some species without excessively affecting profitability (Brčić et al. 2016). Several studies have investigated the functioning and release efficiency potential of SMPs, but the release efficiency of SMPs has often been estimated to be low due to the low probability of contact of the fish with the panel (Herrmann et al. 2014, Alzorriz et al. 2016, Brčić et al. 2018). There have been attempts to improve the fishpanel contact probability by inserting stimulating devices in the gear. Stimulators are designed to trigger fish escape behaviour, but the results obtained so far have shown varying degrees of success (e.g. Glass and Wardle 1995, Herrmann et al. 2014, Grimaldo et al. 2017). Mechanical stimulators have been shown to reduce the retention rate of some juvenile fish species (e.g. Kim and Whang 2010), and in some cases light-based stimulators have been able to induce fish escape behaviour through the escape path (e.g. Hannah et al. 2015, Lomeli et al. 2018).

The main goal of the present study was to determine whether the release efficiency of an SMP installed at the top panel of the extension piece of the trawl could be improved by applying different modifications: i) adding white LED lights at different positions of the panel, ii) changing the size of the panel, and iii) changing the position of the panel in the trawl. This study focused on hake (Merluccius merluccius) and blue whiting (Micromesistius poutassou), which are two common gadoids in the northeast Atlantic and are important species in this fishery (Rochet et al. 2014).

\section{MATERIALS AND METHODS}

\section{Sea trials and data collection}

Sea trials were carried out on board the R/V Emma Bardan (29 m length overall; $900 \mathrm{~kW}$ ) from 1 to 15

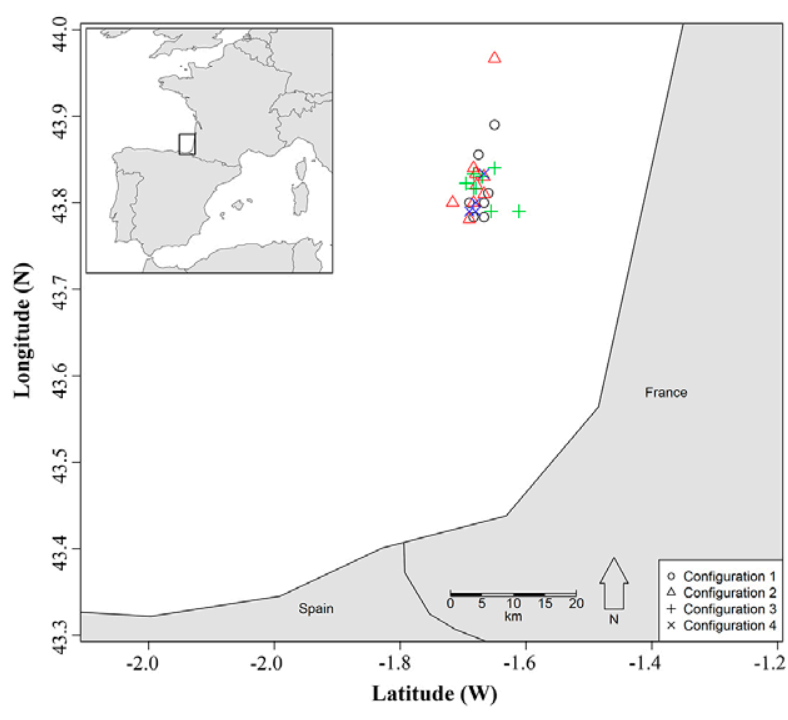

Fig. 1. - Sampling area and positions of the experimental hauls. Different symbols represent the configurations tested during each haul. Conf. 1: a standard SMP inserted in the upper panel with 10 white LED lights placed longitudinally over it. Conf. 2: the same as Conf. 1 , but with 10 white LED lights placed longitudinally in the lower panel in front of the SMP. Conf. 3: a large SMP inserted in the upper panel. Conf. 4: a standard SMP inserted in the lower panel. Standard SMP: mesh size (M), $82.7 \mathrm{~mm}$; area (A), $2.64 \mathrm{~m}^{2}$. Large SMP: (M), $80.0 \mathrm{~mm}$; (A), $4.77 \mathrm{~m}^{2}$.

June 2018 in the Bay of Biscay (ICES division VIIIb) (Fig. 1). All hauls were carried out during daylight.

A four-panel bottom trawl (GOC73; Bertrand et al. 2000) was used. This trawl was built according to the standard bottom trawl survey manual for the Mediterranean (Anonymous 2016). The towing rig was spread with a set of Morgère doors (Morgère WH S8 type, $2.6 \mathrm{~m}^{2}, 350 \mathrm{~kg}$ ), $100 \mathrm{~m}$ sweeps, and a light rockhopper ground gear (with $3 \times 40 \mathrm{~kg}$ chain $+15 \mathrm{~kg}$ chain on the bosom). The trawl had a headline of $35.7 \mathrm{~m}$ and a fishing line of $40.0 \mathrm{~m}$. While fishing, the trawl had a horizontal opening of $16.0 \mathrm{~m}$ and a vertical opening of between 2.7 and $3.2 \mathrm{~m}$. We inserted an SMP into the extension piece of the trawl, $1 \mathrm{~m}$ in front of the joint between the codend and the extension piece (Fig. 2). The SMP was placed either in the upper or the lower panel and was of different sizes depending on the configuration tested (Fig. 2). Configurations 1 and 2 were designed to determine the release efficiency of a standard SMP (mesh size $82.7 \mathrm{~mm}$, area $2.64 \mathrm{~m}^{2}$ ) with white LED lights attached in the upper and lower panel of the extension piece, respectively. Configuration 3 was designed to determine the release efficiency of a larger SMP (mesh size $80.0 \mathrm{~mm}$, area $4.77 \mathrm{~m}^{2}$ ) in the upper panel of the extension piece, while configuration 4 tested the release efficiency of the standard SMP in the lower panel of the extension piece. In every case, codend release efficiency and combined retention probability were also estimated. A total of 28 experimental hauls were conducted, the towing speed was between 3.0 and 3.3 knots, and depths varied between 108 and $122 \mathrm{~m}$.

The codend (CD) used together with the panel was $7.0 \mathrm{~m}$ long (72.8 $\mathrm{mm}$ mesh size, $4 \mathrm{~mm}$ polyamide (PA) double twine). The SMP cover (PC) was $13 \mathrm{~m}$ long 

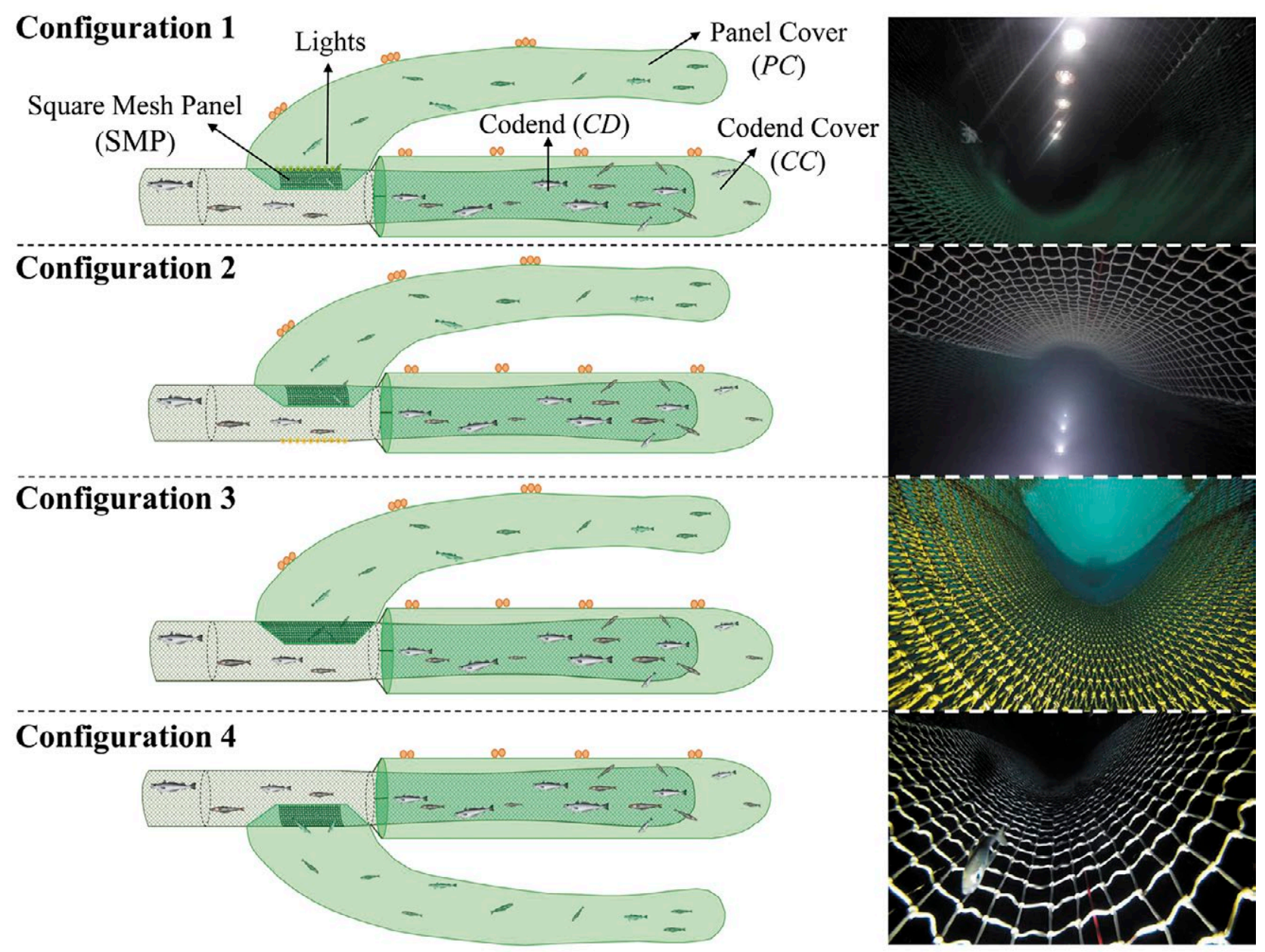

Fig. 2. - Representation of the four gear configurations tested (see explanations in Fig. 1).

(26.1 $\mathrm{mm}$ mesh size, $1.2 \mathrm{~mm}$ PA twine), and the codend cover (CC) was $9 \mathrm{~m}$ long $(26.5 \mathrm{~mm}$ mesh size, $1.3 \mathrm{~mm}$ PA twine). Each experimental haul was carried out with one configuration at a time. Hake and blue whiting individuals caught were measured to the nearest centimetre below (Table 1). The minimum conservation reference size (MCRS) for hake is $27 \mathrm{~cm}$ total length (TL). For blue whiting, which does not have an MCRS, its marketable size limit is estimated to be 18 $\mathrm{cm}$ TL. This TL is based on a regulation that establishes a maximum of 30 individuals of blue whiting per kilo for commercialization (Dorel 1986, EC 1996).

\section{Selectivity model}

The number of fish of length $l$ retained in the three compartments (CD, PC and CC) can be modelled using a multinomial distribution with length-dependent probability of being retained in the codend $r_{\text {comb }}(l)$; escaping through the SMP $e_{\mathrm{SMP}}(l)$; and escaping through the codend $e_{\text {codend }}(l)$. The combined retention can be modelled as follows, where $l$ represents fish length:

$$
r_{\text {comb }}(l)=1-e_{\mathrm{SMP}}(l)-e_{\text {codend }}(l)
$$

First, fish arrive inside the extension piece where the SMP is located, and they can either actively contact the SMP (first selection process) or simply continue to drift towards the codend. We assumed that the probability for fish to contact the panel could be modelled with the length-independent parameter $C_{\mathrm{SMP}} . C_{\mathrm{SMP}}$ quantifies the fraction of fish that contact the device, assuming they enter the zone of the device in the trawl and are therefore subjected to a size-dependent probability of escaping through it. This leads to the following model for $e_{\mathrm{SMP}}(l)$ :

$$
e_{\mathrm{SMP}}(l)=C_{\mathrm{SMP}} \times\left(1-r c_{\mathrm{SMP}}\left(l, v_{\mathrm{SMP}}\right)\right),
$$

where $r c_{\mathrm{SMP}}\left(l, v_{\mathrm{SMP}}\right)$ is the selectivity model for fish making contact with the SMP and having a suitable orientation to achieve a size-dependent probability of passing through the SMP mesh, and $\boldsymbol{v}_{\mathrm{SMP}}$ are the parameters in the model $r c_{\mathrm{SMP}}\left(l, v_{\mathrm{SMP}}\right)$. We assumed that $r c_{\mathrm{SMP}}\left(l, \boldsymbol{v}_{\mathrm{SMP}}\right)$ can be described by one of the standard $\mathrm{S}$-shaped size selection models for trawl gears. We considered four S-shaped size selection curves: Logit, Probit, Gompertz and Richard. Further information about these models, their respective parameters $\boldsymbol{v}$, and estimation of the selectivity parameters L50 and SR (L50 is the length at which a fish has a 50\% chance of being retained by the SMP, whereas SR is the difference between L75 and L25) can be found in Wileman et al. (1996). 
Table 1. - Summary of data collected for hake and blue whiting retained in the SMP cover (PC), codend (CD) and codend cover (CC). The raised number of fish measured is given in brackets.

\begin{tabular}{|c|c|c|c|c|c|}
\hline & Configuration no. & 1 & 2 & 3 & 4 \\
\hline Hake & $\begin{array}{l}\text { No. hauls } \\
\text { Length range }(\mathrm{TL}, \mathrm{cm}) \\
n P C \\
n C D \\
n C C\end{array}$ & $\begin{array}{c}7 \\
7-48 \\
1(1) \\
215(215) \\
1011(1011)\end{array}$ & $\begin{array}{c}9 \\
7-59 \\
9(9) \\
381(381) \\
1656(2769)\end{array}$ & $\begin{array}{c}8 \\
7-60 \\
48(48) \\
807(807) \\
1909(1909)\end{array}$ & $\begin{array}{c}4 \\
6-53 \\
820(820) \\
244(244) \\
1856(1856)\end{array}$ \\
\hline Blue whiting & $\begin{array}{l}\text { No. hauls } \\
\text { Length range }(\mathrm{cm}) \\
n P C \\
n C D \\
n C C\end{array}$ & $\begin{array}{c}7 \\
12-33 \\
158(158) \\
1259(1986) \\
205(205)\end{array}$ & $\begin{array}{c}4 \\
19-32 \\
70(70) \\
562(871) \\
47(47)\end{array}$ & $\begin{array}{c}6 \\
12-32 \\
430(1071) \\
616(1260) \\
57(57)\end{array}$ & $\begin{array}{c}3 \\
9-30 \\
7(7) \\
290(548) \\
196(196)\end{array}$ \\
\hline
\end{tabular}

To model the size-dependent codend retention probability $r c_{\text {codend }}\left(l, v_{\text {codend }}\right)$, we assumed that every fish entering the codend came into contact with the codend meshes and that $r c_{\text {codend }}\left(l, \boldsymbol{v}_{\text {codend }}\right)$, like $r c_{\mathrm{SMP}}\left(l, \boldsymbol{v}_{\mathrm{SMP}}\right)$ could be modelled by a Logit, Probit, Gompertz or Richard model. The estimation of codend escape involves solely the fish that have not escaped through the SMP. The above considerations led to the following model for $e_{\text {codend }}(l)$ :

$e_{\text {codend }}(l)=\left(1-r c_{\text {codend }}\left(l, v_{\text {codend }}\right)\right) \times\left(1-e_{\mathrm{SMP}}\left(l, C_{\mathrm{SMP}}, \boldsymbol{v}_{\mathrm{SMP}}\right)\right)$

(3)

\section{Model estimation}

The values of $C_{\mathrm{SMP}}, \boldsymbol{v}_{\mathrm{SMP}}$, and $\boldsymbol{v}_{\text {codend }}$ for selection models (1)-(3) were obtained for each species and gear configuration using maximum likelihood estimation (MLE) by pooling the experimental data over the hauls $j(1$ to $m$ ) with the specific gear configuration and minimizing:

$$
\begin{aligned}
-\sum_{l} \sum_{j=1}^{m}\left\{\frac{n C D_{l j}}{q C D_{j}} \times \ln \left(r_{\text {comb }}\left(l, C_{S M P}, \boldsymbol{v}_{S M P}, \boldsymbol{v}_{\text {codend }}\right)\right)+\right. \\
+\frac{n P C_{l j}}{q P C_{j}} \times \ln \left(e_{S M P}\left(l, C_{S M P}, v_{S M P}\right)\right)+ \\
\left.+\frac{n C C_{l j}}{q C C_{j}} \times \ln \left(e_{\text {codend }}\left(l, C_{S M P}, \boldsymbol{v}_{S M P}, \boldsymbol{v}_{\text {codend }}\right)\right)\right\}
\end{aligned}
$$

where for each haul $j$ and length class $l, n C D_{\mathrm{lj}}, n P C_{\mathrm{lj}}$ and $n C C_{1 \mathrm{j}}$ are the numbers of individuals length-measured in the $\mathrm{CD}, \mathrm{PC}$ and $\mathrm{CC}$, respectively, and $q C D_{\mathrm{j}}$,

Table 2. - Based on Equations (1)-(3), selectivity results for the two species, the different configurations, and compartments (square mesh

\begin{tabular}{|c|c|c|c|c|}
\hline Hake & 1 & Confi & on no. & 4 \\
\hline \multicolumn{5}{|l|}{ Model } \\
\hline$r c_{\mathrm{SMP}}$ & Logit & Logit & Logit & Gompertz \\
\hline & Richard & Gompertz & Gompertz & Richard \\
\hline \multicolumn{5}{|l|}{$\mathrm{L} 50(\mathrm{~cm})$} \\
\hline SMP & $11.95(0.10-11.96)$ & $16.05(11.79-16.08)$ & $32.07(31.04-32.10)$ & $18.76(1.20-23.70)$ \\
\hline $\mathrm{CD}$ & $18.06(16.46-20.19)$ & $20.42(17.14-24.38)$ & $15.71(14.52-17.05)$ & $22.27(19.21-26.00)$ \\
\hline Comb & $18.06(16.46-20.19)$ & $20.42(17.14-24.38)$ & $15.79(14.61-17.13)$ & $22.87(19.78-26.60)$ \\
\hline \multicolumn{5}{|l|}{$\mathrm{SR}(\mathrm{cm})$} \\
\hline SMP & $0.10(0.10-0.91)$ & $0.10(0.10-2.43)$ & $0.10(0.10-0.10)$ & $6.69(0.10-12.30)$ \\
\hline $\mathrm{CD}$ & $4.88(2.67-6.24)$ & $7.92(4.98-11.82)$ & $4.99(3.91-6.34)$ & $7.89(4.63-11.78)$ \\
\hline Comb & $4.88(2.67-6.24)$ & $7.92(4.98-11.81)$ & $5.15(4.06-6.52)$ & 7.75 (4.94-11.04) \\
\hline$C_{\mathrm{SMP}}$ & $0.00(0.00-0.01)$ & $0.00(0.00-0.01)$ & $0.02(0.01-0.03)$ & $0.33(0.10-0.94)$ \\
\hline Dev & 21.82 & 62.24 & 102.44 & 121.27 \\
\hline DOF & 66 & 69 & 81 & 70 \\
\hline p-value & 1.00 & 0.71 & 0.05 & 0.00 \\
\hline Blue whiting & & Confi & on no. & \\
\hline & 1 & 2 & 3 & 4 \\
\hline \multicolumn{5}{|l|}{ Model } \\
\hline$r c_{\mathrm{SMP}}$ & Logit & Gompertz & Gompertz & Logit \\
\hline$r c_{\text {codend }}$ & Gompertz & Gompertz & Gompertz & Logit \\
\hline \multicolumn{5}{|l|}{$\mathrm{L} 50(\mathrm{~cm})$} \\
\hline SMP & $77.74(29.30-200.00)$ & $29.62(20.19-72.18)$ & 32.39 (29.81-197.57) & $29.00(0.10-200.00)$ \\
\hline $\mathrm{CD}$ & $19.51(14.87-22.23)$ & $21.07(0.51-21.97)$ & $18.33(11.28-22.23)$ & $23.76(20.67-25.54)$ \\
\hline Comb & $19.85(15.57-22.40)$ & $21.29(9.26-22.21)$ & $23.96(17.01-160.65)$ & $23.80(20.77-25.57)$ \\
\hline \multicolumn{5}{|l|}{$\mathrm{SR}(\mathrm{cm})$} \\
\hline SMP & $3.32(0.10-6.10)$ & $0.90(0.10-20.79)$ & $1.99(0.10-48.72)$ & $0.10(0.10-8.37)$ \\
\hline $\mathrm{CD}$ & $5.11(2.76-9.09)$ & $3.03(1.98-13.71)$ & $4.50(1.16-6.73)$ & $4.11(2.49-7.81)$ \\
\hline Comb & $5.84(3.11-10.44)$ & $3.51(2.43-13.62)$ & $14.26(8.85-176.98)$ & $4.16(2.50-7.87)$ \\
\hline$C_{\mathrm{SMP}}$ & $0.07(0.05-0.09)$ & $0.07(0.04-1.00)$ & $0.45(0.26-0.66)$ & $0.01(0.00-0.02)$ \\
\hline Dev & 28.93 & 97.03 & 25.81 & 12.70 \\
\hline DOF & 29 & 23 & 23 & 27 \\
\hline p-value & 0.47 & 0.00 & 0.31 & 0.99 \\
\hline
\end{tabular}
panel (SMP); codend (CD), and combined effect of the codend and the SMP (Comb)). Estimated selectivity parameters, 95\% CIs (in brackets), and fit statistics are provided. DOF, degrees of freedom; Dev, deviance. 
$q P C_{\mathrm{j}}$, and $q C C_{\mathrm{j}}$ are their respective subsampling factors (ratio of length measured to total number of fish caught in each compartment). In total, 16 models were considered based on the combination of the four Sshaped functions considered for $r c_{\mathrm{SMP}}(l)$ and $r c_{\text {codend }}(l)$. The model showing the lowest Akaike information criterion value (AIC; Akaike 1974) was selected. MLE using expression (4) with (1) to (3) requires pooling experimental data over hauls. This results in stronger data for average size-selectivity estimation but does not consider explicit variation in selectivity between hauls (Fryer 1991). To account for the effect of both between-haul variation and the uncertainty in individual hauls when estimating uncertainty in size selection, we applied a double bootstrap method (Herrmann et al. 2012). We estimated the $95 \%$ Efron percentile confidence intervals (95\% CIs) (Efron 1982) for $e_{\mathrm{SMP}}(l)$, $e_{\text {codend }}(l)$ and $r_{\text {comb }}(l)$ curves by carrying out 1000 bootstrap iterations.

Evaluation of the ability of the models to describe the experimental data was based on inspecting the fit statistics (i.e. the p-value and the model deviance versus the degrees of freedom (DOF)) following the procedures described by Wileman et al. (1996). The p-value expresses the likelihood of obtaining at least as big a discrepancy as that observed between the fitted model and the observed experimental data by coincidence. In cases with poor fit statistics ( $p$-value $<0.05$; deviance $>>D O F$ ), the residuals were inspected to determine whether the poor result was due to structural problems when describing the experimental data using the model or to over-dispersion in the data (Wileman et al. 1996). All analyses were performed using the software tool SELNET (Herrmann et al. 2012).

To infer the effect of the different configurations on the length-dependent SMP escape probability, we compared the selectivity curves estimated between configurations (SMP release efficiency and combined selectivity). We first compared the effect on the release efficiency through the SMP of white LED lights placed at different positions in the extension piece (Configuration 1 vs. 2). We then compared the effect of increasing the SMP's area relative to the effect of the standard SMP placed on the lower panel of the extension piece (Configuration 3 vs. 4).

\section{RESULTS}

Table 1 shows the number of hake and blue whiting captured and the length measured in each of the configurations and compartments. A number of other species were caught as well: horse mackerel (Trachurus trachurus), mackerel (Scomber scombrus), megrim
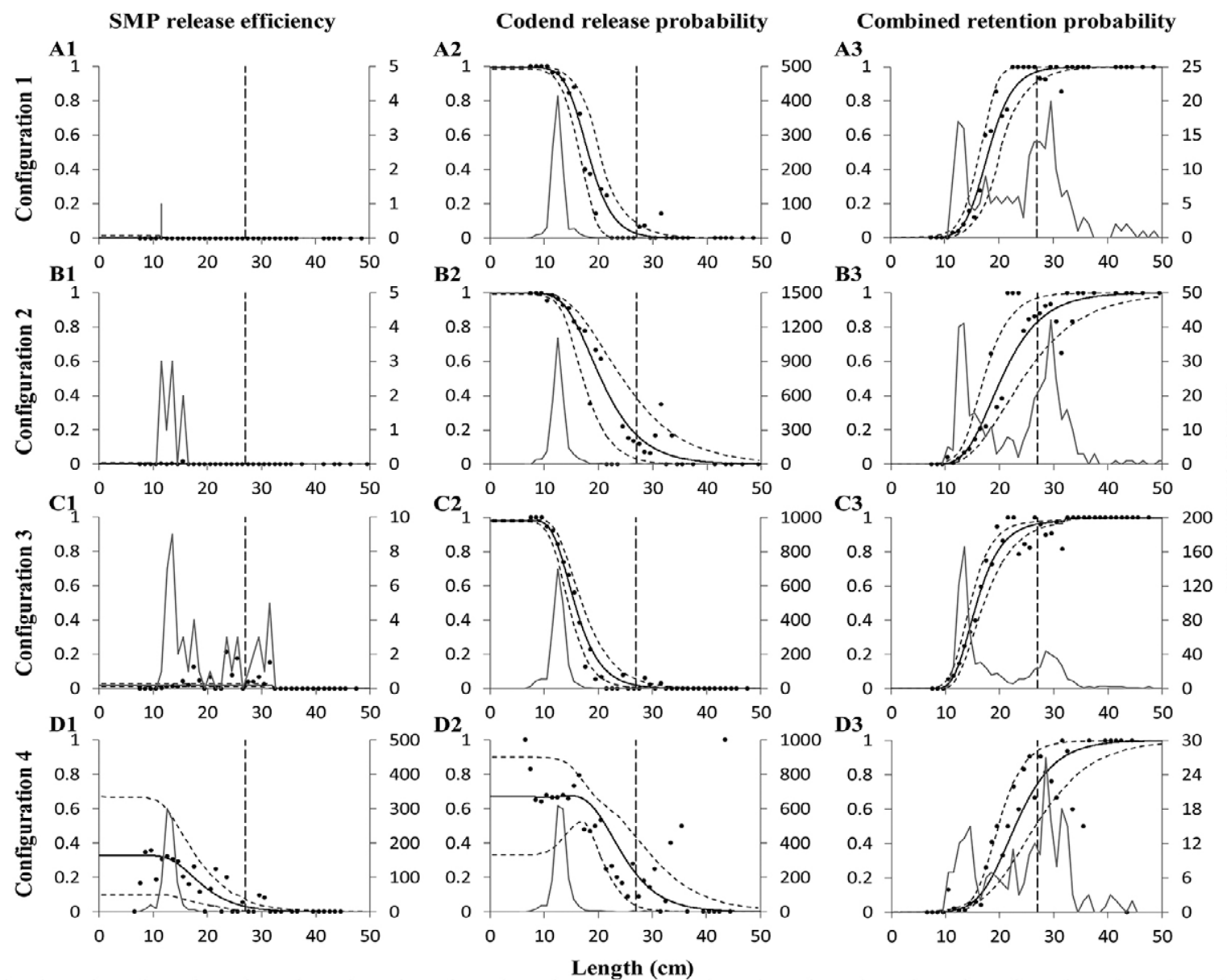

Fig. 3. - Escape probability through the SMP panel and the codend, and probability of being retained in the codend for hake in the different configurations tested. Grey lines, raised catch size-frequency distributions; solid circles, mean experimental rates per size class; solid black lines, mean escapement curves for SMP (A1-D1), codend (A2-D2) and combined retention (A3-D3). All of them show 95\% CIs (dashed lines). Vertical stippled lines show the MCRS of hake: $27 \mathrm{~cm}$ TL. 

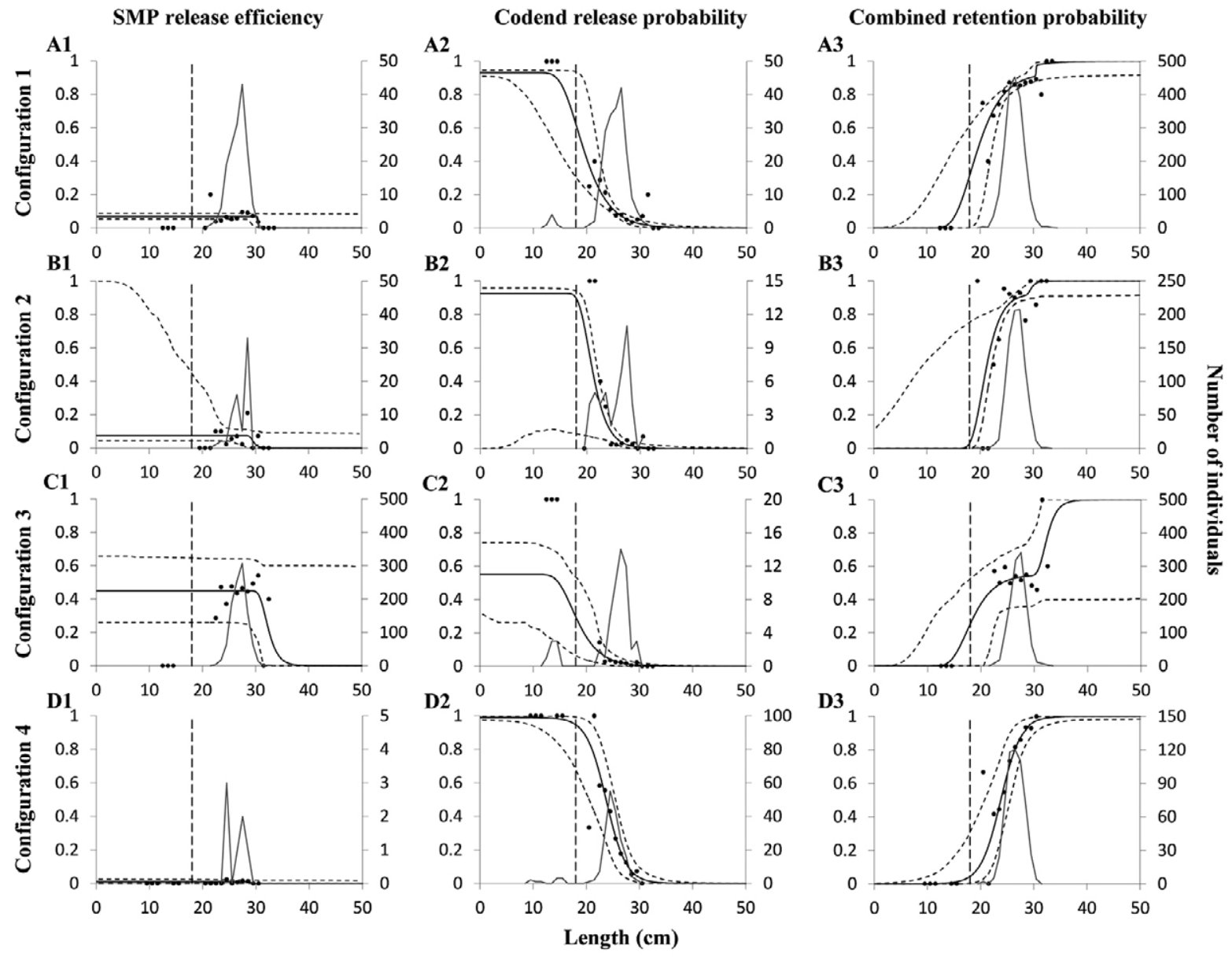

Fig. 4. - Escape probability through the panel and the codend, and probability of being retained in the codend for blue whiting in the different configurations tested. Grey lines, raised catch size-frequency distributions; solid circles, mean experimental rates per size class; solid black lines, mean escapement curves for SMP (A1-D1), codend (A2-D2) and combined retention (A3-D3). All of them show 95\% CIs (dashed lines). Vertical stippled lines show the estimated minimum marketable size of blue whiting: $18 \mathrm{~cm}$ TL.
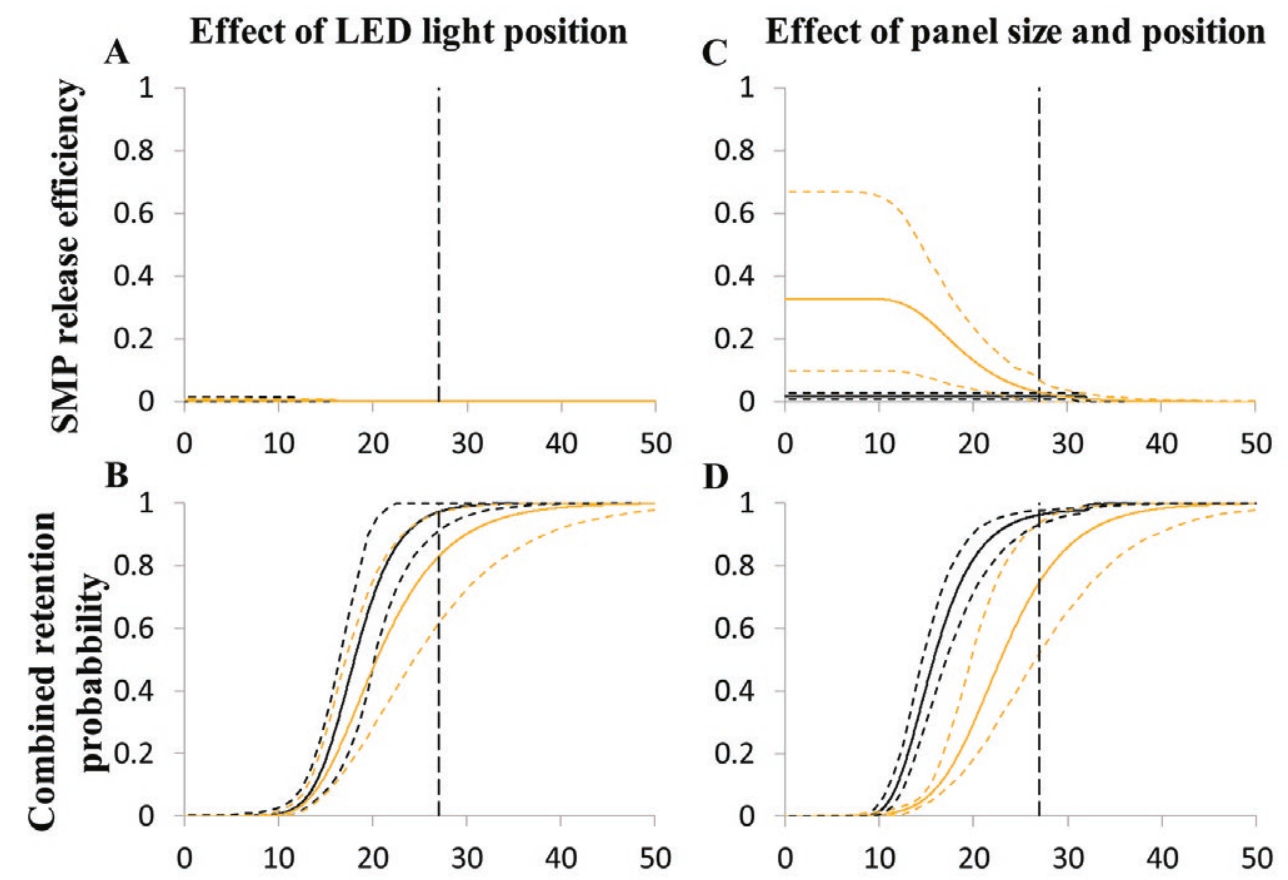

Fig. 5. - Comparison of the SMP release efficiency and combined size selection of the gear for hake among configurations applied in each test. A, B, effect of LED light position: black curve, conf. 1; grey curve, conf. 2. C, D, effect of panel size and position: black curve, conf. 3; yellow curve, conf. 4 . The dashed lines show 95\% CIs for each selectivity curve. Vertical stippled lines show the MCRS of hake: $27 \mathrm{~cm}$ TL. 

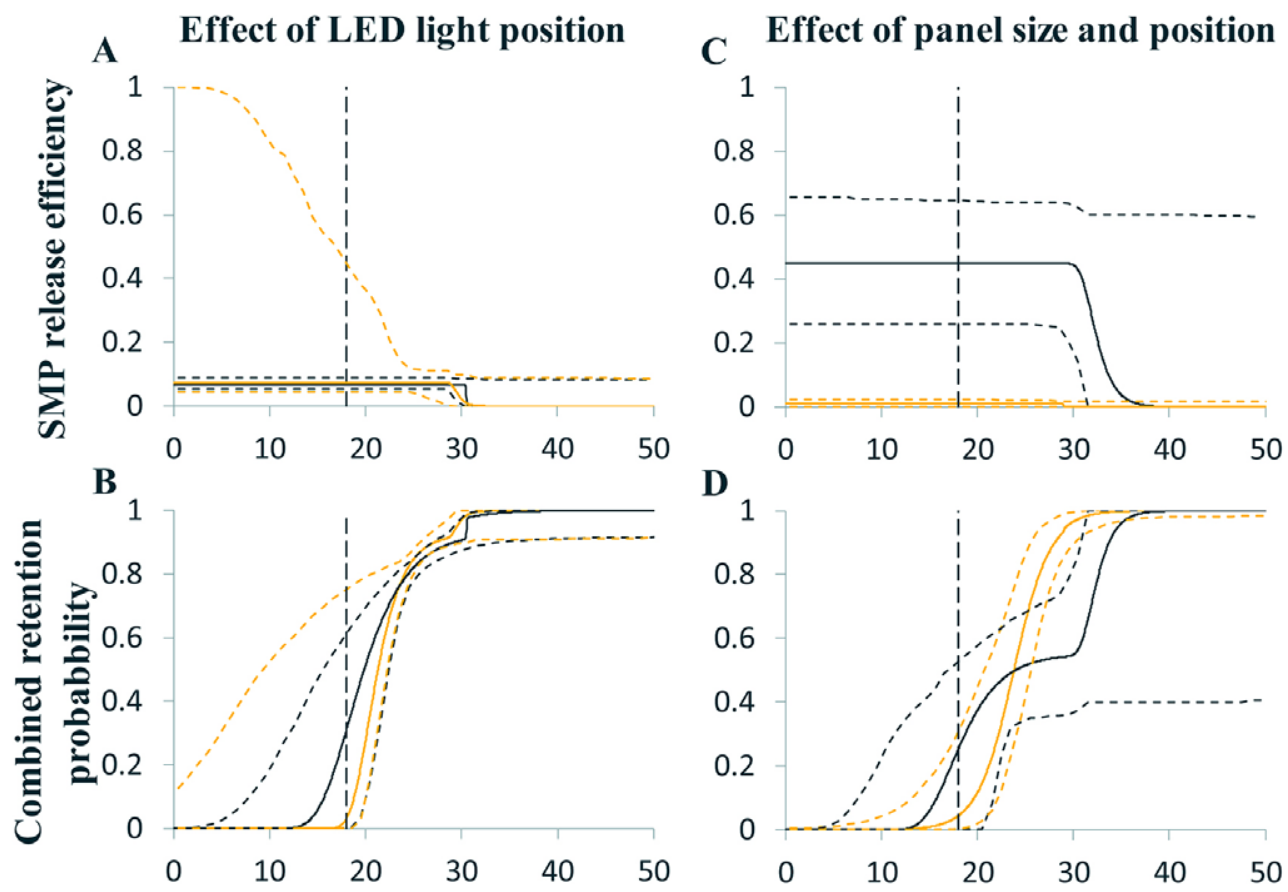

Fig. 6. - Comparison of the SMP release efficiency and combined size selection of the gear for blue whiting among configurations applied in each test. A, B, effect of LED light position: black curve, conf. 1; grey curve, conf. 2. C, D, effect of panel size and position: black curve, conf. 3; yellow curve, conf. 4. The dashed lines show 95\% CIs for each selectivity curve. Vertical stippled lines show the estimated minimum marketable size of blue whiting: $18 \mathrm{~cm}$ TL.

(Lepidorhombus spp.) and boarfish (Capros aper). However, the numbers of these species caught were too low for selectivity analysis.

Table 2 summarizes the model combinations for SMP release (Equation 2) and codend release (Equation 3) resulting in the lowest AIC value for each configuration tested and the selectivity parameters estimated. Because the p-value was greater than 0.05 in most cases, the fit statistics showed that the models were able to describe the experimental data well for both species. The p-values lower than 0.05 obtained for hake when the SMP was placed in the lower panel and for blue whiting when lights were in the lower panel were attributed to over-dispersion in the data.

The release efficiency of hake and blue whiting through the SMP was low (Figs 3 and 4), except for hake when configuration 4 was applied and for blue whiting when configuration 3 was tested (Figs 3D1 and $4 \mathrm{C} 1$ ). This was also shown in the $C_{\mathrm{SMP}}$ values obtained (Table 2), which were estimated to be 0.33 for hake in configuration 4 and 0.45 for blue whiting in configuration 3 . Figures 3 A1-3, B1-3 and 4A1-3, B1-3 also show that LED lights, no matter the position, did not affect the escape probability through the SMP for either species.

Comparing both the SMP release and the combined SMP and codend retention probability curves between configurations 1 and 2 and between configurations 3 and 4 (Figs 5 and 6) enabled us to investigate the effect of each design change. No matter where the lights were located, the release of hake and blue whiting through the SMP remained very low due to the low contact probability and showed no significant differences between configurations (Figs 5A and 6A). The escape mainly happened through the codend (Figs 3A2-D2 and 4A2-D2). The release efficiency of hake below $24 \mathrm{~cm}$ TL was significantly higher when the standard SMP was placed in the lower panel than with the rest of the configurations applied (Fig. 5C). This finding may be related to the behaviour of this species (Alzorriz et al. 2016, Santos et al. 2016). On the other hand, the release efficiency of blue whiting was significantly higher when the large SMP was installed in the upper panel (Fig. 6C). However, this effect had almost no impact on the combined retention probability of the SMP and codend because codend size selection would release any small individual retained during the first selection process by the SMP (Fig. 6D). The combined retention was significantly lower only for larger individuals (between 26 and $30 \mathrm{~cm}$ TL) that did not escape through the codend.

\section{DISCUSSION}

Earlier studies by Alzorriz et al. (2016) and Brčić et al. $(2016,2018)$, which were carried out in the Atlantic Ocean and the Mediterranean Sea, respectively, showed that few individuals of hake escaped through SMPs located in front of the codend and on the top panel of the trawl. These low escape rates were attributed mainly to the low contact probability between the fish and the SMP, which resulted in few fish being sizeselected by the panel. This low contact for hake was also found in the present study (the proportion of fish that contacted the SMP placed in the top panel of the trawl was not higher than 2\% (CI: 0-3\%) for any of the three different configurations tested). When the SMP was inserted in the lower panel of the trawl, the release 
efficiency of the SMP was significantly improved. Specifically, the release efficiency of the standard SMP placed in the lower panel for hake was significantly higher than that of the large SMP placed in the upper panel for individuals up to $24 \mathrm{~cm}$ TL (Fig. 5C). However, for the combined size selection, the effect of placing the SMP in the lower panel would only affect hake between 11 and $28 \mathrm{~cm}$ TL because hake below 11 $\mathrm{cm}$ TL would be released by the codend meshes (Fig. 5D). As in the present study, Santos et al. (2016) also studied the effect of changing the position of a $100 \mathrm{~mm}$ SMP. In their case, they tested the release efficiency of $10 \mathrm{~m}$ long SMPs integrated into the sides of the trawl in the last tapered section of the belly. The system was supplemented by a pentagon-shaped device that was mounted in the belly to guide fish towards the SMPs located on the sides. Their results showed that the contact probability of hake for SMPs inserted on the sides of the trawl far exceeded that of an equivalent SMP installed on the top panel of the gear. Thus, the results obtained by Santos et al. (2016) together with the results obtained in our study encourage testing positions other than the top panel of the trawl for SMPs that aim to release undersized individuals of hake.

The results of the present study also showed that hake and blue whiting responded differently to the modifications applied to the SMP. The contact with the SMP estimated when the SMP was located at the top panel of the trawl was significantly higher for blue whiting than for hake. Furthermore, when the large SMP was inserted in the upper panel, the probability of contact of blue whiting individuals with the SMP increased from values below $7 \%$ for the rest of the configurations to 45\% (CI: 26-66\%) (Fig. 4C1; Table 2 ), whereas the probability of contact of hake with the same configuration was estimated to be $2 \%$ (CI: $1-3 \%$ ) (Fig. 3C1; Table 2). This result clearly demonstrates that the behavioural differences between hake and blue whiting in the aft part of the trawl can be substantial.

When white LED lights were installed on the SMP or in the panel right below the SMP, the release efficiency through the SMP was not significantly improved for either hake or blue whiting. Grimaldo et al. (2017) tested whether green LED lights could improve the release efficiency of cod (Gadus morhua) and haddock (Melanogrammus aeglefinus) through a square mesh section. No significant differences were found for cod, whereas the results for haddock only indicated an effect for the smaller individuals. Despite cod and haddock having different behavioural patterns in the aft part of a trawl (Engås et al. 1998, Ferro et al. 2007, Sistiaga et al. 2016), somewhat like hake and blue whiting, the results in the present study showed no difference in the behavioural response of hake and blue whiting to LED lights.

As in several previous studies, such as those on the Norwegian bottom trawl gadoid fishery in the Barents Sea (Engås et al. 1998) and the mixed whitefish trawl fishery in the North Sea (Ferro et al. 2007), our results highlight species-related behavioural differences in the aft part of the trawl. In some cases, these behavioural differences have been used to sort different species inside the trawl (Engås et al. 1998). Considering the behavioural differences between blue whiting and hake reported here and the poor contact of hake with the SMP installed on the top panel reported in other studies (Alzorriz et al. 2016, Brčić et al. 2016, 2018), it can be speculated whether the Basque mixed bottom trawl fishery is suited for species-specific selective measures in the aft part of the trawl. The results of this study support the hypothesis that modifications applied to the SMP can influence the release efficiency of hake and blue whiting in different ways, mainly determined by the specific behaviour of each species inside the trawl. However, they also illustrate the challenge of improving the selective properties of a gear in a mixed fishery simultaneously for more than one species. Moreover, this study demonstrated that fish behaviour is an important issue that should be considered when designing and implementing selectivity devices.

\section{ACKNOWLEDGEMENTS}

We would like to thank the editor and two anonymous reviewers for their valuable comments, which have certainly improved the manuscript. We thank the Spanish Ministry of Agriculture, Fisheries, Food and Environment for funding the research and for use of the R/V Emma Bardan, and we thank the crew of the Emma Bardan for their valuable assistance during the study.

\section{REFERENCES}

Akaike H. 1974. A New Look at the Statistical Model Identification. In: Parzen E., Tanabe K., Kitagawa G. (eds), Selected Papers of Hirotugu Akaike. Springer Series in Statistics (Perspectives in Statistics). Springer, New York, pp. 215-222 https://doi.org/10.1007/978-1-4612-1694-0_16

Alzorriz N., Arregi L., Herrmann B., et al. 2016. Questioning the effectiveness of technical measures implemented by the Basque bottom otter trawl fleet: Implications under the EU landing obligation. Fish. Res. 175: 116-126.

https://doi.org/10.1016/j.fishres.2015.11.023

Anonymous. 2016. MEDITS-Handbook Version 8. MEDITS Working Group, pp. 25-31.

http://www.sibm.it/MEDITS\%202011/docs/Medits_Handbook_2016_version_8_042016.pdf

Bahamon N., Sardà F., Suuronen P. 2006. Improvement of trawl selectivity in the NW Mediterranean demersal fishery by using a $40 \mathrm{~mm}$ square mesh codend. Fish. Res. 81: 15-25. https://doi.org/10.1016/j.fishres.2006.05.020

Bertrand J.A., De Sola L.G., Papaconstantinou C., et al. 2000. An international bottom trawl survey in the Mediterranean: the MEDITS programme. IFREMER Actes Colloq. 76-96.

Brčić J., Herrmann B., Sala A. 2016. Can a square-mesh panel inserted in front of the codend improve the exploitation pattern in Mediterranean bottom trawl fisheries? Fish. Res. 183: 13-18. https://doi.org/10.1016/j.fishres.2016.05.007

Brčić J., Herrmann B., Sala A. 2018. Can a square-mesh panel inserted in front of the cod end improve size and species selectivity in Mediterranean trawl fisheries? Can. J. Fish. Aquat. Sci. 75: 704-713. https://doi.org/10.1139/cjfas-2017-0123

De Vos B.I., Döring R., Aranda M., et al. 2016. New modes of fisheries governance: Implementation of the landing obligation in four European countries. Mar. Policy 64: 1-8. https://doi.org/10.1016/j.marpol.2015.11.005

Dorel D. 1986. Poissons de l'Atlantique nord-est: Relations taillepoids. IFREMER Report, $165 \mathrm{pp}$ https://archimer.ifremer.fr/doc/1986/rapport-1289.pdf

EC. 1996. Council Regulation (EC) No 2406/96 of 26 November 1996 laying down common marketing standards for certain 
fishery products. OJ L 334, 23.12.1996, pp. 1-15. https://eur-lex.europa.eu/legal-content/EN/TXT/PDF/?uri=CE LEX:31996R2406\&from=ES

EC. 2006. Council Regulation (EC) No. 51/2006 of 22 December 2005 fixing for 2006 the fishing opportunities and associated conditions for certain fish stocks and groups of fish stocks, applicable in Community waters and, for Community vessels, in waters where catch limitations are required. OJ L 16, 20.1.2006, pp.1-183.

https://eur-lex.europa.eu/legal-content/EN/TXT/PDF/?uri=CE LEX:32006R0051\&from=EN

Efron B. 1982. The jackknife, the bootstrap and other resampling plans. SIAM Monograph No. 38, CBSM-NSF. https://doi.org/10.1137/1.9781611970319

Engås A., Jørgensen T., West C.W. 1998. A species-selective trawl for demersal gadoid fisheries. ICES J. Mar. Sci. 55: 835-845. https://doi.org/10.1006/jmsc.1998.0352

EU. 2013. Regulation (EU) No 1380/2013 of the European Parliament and of the Council of 11 December 2013 on the Common Fisheries Policy, amending Council Regulations (EC) No 1954/2003 and (EC) No 1224/2009 and repealing Council Regulations (EC) No 2371/2002 and (EC) No 639/2004 and Council Decision 2004/585/EC. OJ L 354, 28.12.2013, pp. 22-61.

https://eur-lex.europa.eu/legal-content/EN/TXT/PDF/?uri=CE LEX:32013R1380\&from=EN

Ferro R.S.T., Jones E.G., Kynoch R.J., et al. 2007. Separating species using a horizontal panel in the Scottish North Sea whitefish trawl fishery. ICES J. Mar. Sci. 64: 1543-1550. https://doi.org/10.1093/icesjms/fsm099

Fryer R.J. 1991. A model of between-haul variation in selectivity. ICES J. Mar. Sci. 48: 281-290. https://doi.org/10.1093/icesjms/48.3.281

Glass C.W., Wardle C.S. 1995. Studies on the use of visual stimuli to control fish escape from codends. II. The effect of a black tunnel on the reaction behaviour of fish in otter trawl codends. Fish. Res. 23: 165-174. https://doi.org/10.1016/0165-7836(94)00331-P

Grimaldo E., Sistiaga M., Herrmann B., et al. 2017. Improving release efficiency of cod (Gadus morhua) and haddock (Melanogrammus aeglefinus) in the Barents Sea demersal trawl fishery by stimulating escape behaviour. Can. J. Fish. Aquat. Sci. 75: 402-416.

https://doi.org/10.1139/cjfas-2017-0002
Hannah R.W., Lomeli M.J., Jones S.A. 2015. Tests of artificial light for bycatch reduction in an ocean shrimp (Pandalus jordani) trawl: strong but opposite effects at the footrope and near the bycatch reduction device. Fish. Res. 170: 60-67. https://doi.org/10.1016/j.fishres.2015.05.010

Herrmann B., Sistiaga M., Nielsen K.N., et al. 2012. Understanding the size selectivity of redfish (Sebastes spp.) in North Atlantic trawl codends. J. Northwest Atl. Fish. Sci. 44: 1-13. https://doi.org/10.2960/J.v44.m680

Herrmann B., Wienbeck H., Karlsen J.D., et al. 2014. Understanding the release efficiency of Atlantic cod (Gadus morhua) from trawls with a square mesh panel: effects of panel area, panel position, and stimulation of escape response. ICES J. Mar. Sci. 72: 686-696. https://doi.org/10.1093/icesims/fsu124

Kim Y.H., Whang D.S. 2010. An actively stimulating net panel and rope array inside a model cod-end to increase juvenile red seabream escapement. Fish. Res. 106: 71-75. https://doi.org/10.1016/j.fishres.2010.07.005

Lomeli M.J., Groth S.D., Blume M.T., et al. 2018. Effects on the bycatch of eulachon and juvenile groundfish by altering the level of artificial illumination along an ocean shrimp trawl fishing line. ICES J. Mar. Sci. 75: 2224-2234. https://doi.org/10.1093/icesjms/fsy105

Nikolic N., Diméet J., Fifas S., et al. 2015. Efficacy of selective devices in reducing discards in the Nephrops trawl fishery in the Bay of Biscay. ICES J. Mar. Sci. 72: 1869-1881. https://doi.org/10.1093/icesjms/fsv036

Rochet M.J., Arregi L., Fonseca T., et al. 2014. Demersal discard atlas for the South Western Waters. $121 \mathrm{pp}$.

Santos J., Herrmann B., Otero P., et al. 2016. Square mesh panels in demersal trawls: does lateral positioning enhance fish contact probability? Aquat. Living Resour. 29: 302. https://doi.org/10.1051/alr/2016025

Sistiaga M., Brinkhof J., Herrmann B., et al. 2016. Size selective performance of two flexible sorting grid designs in the Northeast Arctic cod (Gadus morhua) and haddock (Melanogrammus aeglefinus) fishery. Fish. Res. 183: 340-351. https://doi.org/10.1016/i.fishres.2016.06.022

Wileman D.A., Ferro R.S.T., Fonteyne R., (ed.). 1996. Manual of methods of measuring the selectivity of towed fishing gears. ICES Coop. Res. Rep. No. 215. 